\title{
Linking larval chironomids to methane: seasonal variation of the microbial methane cycle and chironomid $\delta^{13} \mathrm{C}$
}

\author{
Peter Deines $^{1, *}$, Jonathan Grey ${ }^{1,2}$, Hans-Hermann Richnow ${ }^{3}$, Gundula Eller ${ }^{1}$ \\ ${ }^{1}$ Max Planck Institute for Limnology, Department of Physiological Ecology, August-Thienemann-Str. 2, 24306 Plön, Germany \\ ${ }^{2}$ School of Biological and Chemical Sciences, Queen Mary, University of London, Mile End Road, London E1 4NS, UK \\ ${ }^{3}$ UFZ-Helmholtz Centre for Environmental Research, Permoserstr. 15, 04318 Leipzig, Germany
}

\begin{abstract}
Methane-derived carbon has been shown to be an important carbon source for macroinvertebrates in several studies of lake ecosystems using stable isotopes. Furthermore, season and lake morphology appear to influence the importance of methane as a carbon source. However, rarely have the dynamics of the methane cycle been measured concurrently with the isotope signatures of chironomid larvae. We examined the methane dynamics in 2 lakes with contrasting mixing regimes (polymictic and dimictic), while monitoring corresponding changes in chironomid larval $\delta^{13} \mathrm{C}$ throughout an annual cycle. Both methane turnover rates and abundance of methane-oxidising bacteria were higher in the dimictic lake, where correspondingly lower mean larval $\delta^{13} \mathrm{C}$ values of -44.2 to $-61.7 \%$ were recorded. In contrast, potential methane production and oxidation rates, as well as cell numbers of methane-oxidising bacteria were always lower in the polymictic lake; corresponding larval $\delta^{13} \mathrm{C}$ values ranged from -32.3 to $-29.6 \%$. Furthermore, seasonal variation in larval $\delta^{13} \mathrm{C}$ was more pronounced in the dimictic lake $(-50.1 \pm 5.9 \%)$ compared to the polymictic lake $(-31.1 \pm 1.2 \%)$, reflecting the amplitude of turnover rates. This suggests strongly that lake characteristics have an influence on methane turnover rates and, in conjunction with season, affect the subsequent incorporation of methane-derived carbon into freshwater food webs via macroinvertebrates.
\end{abstract}

KEY WORDS: Methane cycle $\cdot$ Stable isotopes $\cdot$ Chironomid larvae $\cdot$ Seasonality

\section{INTRODUCTION}

Stable isotope analyses are increasingly used in aquatic ecosystem studies to elucidate food web structure, as well as sources and fluxes of nutrients through ecosystems (e.g. Peterson \& Fry 1987, Cabana \& Rasmussen 1996, Grey et al. 2001). Since the $\delta^{13} \mathrm{C}$ signature of biogenic methane is typically extremely negative compared to phytoplankton-derived carbon (Fry \& Sherr 1984), the flow of methane-derived carbon can be traced through biological communities (e.g. Childress et al. 1986, Fisher 1990, Levin \& Michener 2002). A study by Bunn \& Boon (1993) indicated that biogenic methane may be assimilated into higher trophic levels in freshwater food webs via methane-oxidising bacteria (MOB). More recently, several studies have suggested the importance of methane as a carbon source for macroinvertebrates in freshwater ecosystems, especially for the larvae of certain chironomid taxa (Kiyashko et al. 2001, Grey 2002, Grey et al. 2004a, Kelly et al. 2004, Kohzu et al. 2004). Fig. 1 shows a hypothetical cross-section through the tube of Chironomus plumosus larvae and the processes proposed to be involved in larval acquisition of methanederived carbon.

Kelly et al. (2004) sampled 6 eutrophic lakes and modelled the methane-derived contribution to Chironomus plumosus larval carbon; this ranged from 6 to $58 \%$. They attributed such a range to varying conditions conducive to methane production and oxidation in the surface sediments of the different lakes. Furthermore, in a study of seasonal changes in chironomid $\delta^{13} \mathrm{C}$, marked differences were found in 2 summer-stratified lakes, whereas no seasonality could be detected in a polymic- 
tic lake (Grey et al. 2004b). They speculated that the renewed availability of oxygen at the sediment surface of the stratifying lakes stimulated the growth of MOB, as well as stimulating the chironomid larvae to feed upon the fresh bacterial biomass. Although the aforementioned studies provide convincing indirect isotopic evidence of methane-derived carbon incorporation into freshwater food webs, there has been only 1 study actually characterising methane cycling in parallel to larval $\delta^{13} \mathrm{C}$ signatures in 2 lakes of differing mixing regimes (Eller et al. 2005). This study revealed a correlation between methane turnover rates and chironomid $\delta^{13} \mathrm{C}$, but was limited to 1 sampling event and, thus, did not include seasonality of methane turnover. It was assumed by Grey et al. (2004b) that differences in lake mixing regimes should lead to differences in the seasonal pattern of methane turnover between the lakes, which, consequently, should be reflected in the seasonal changes of larval $\delta^{13} \mathrm{C}$ signatures. To test this assumption, larval

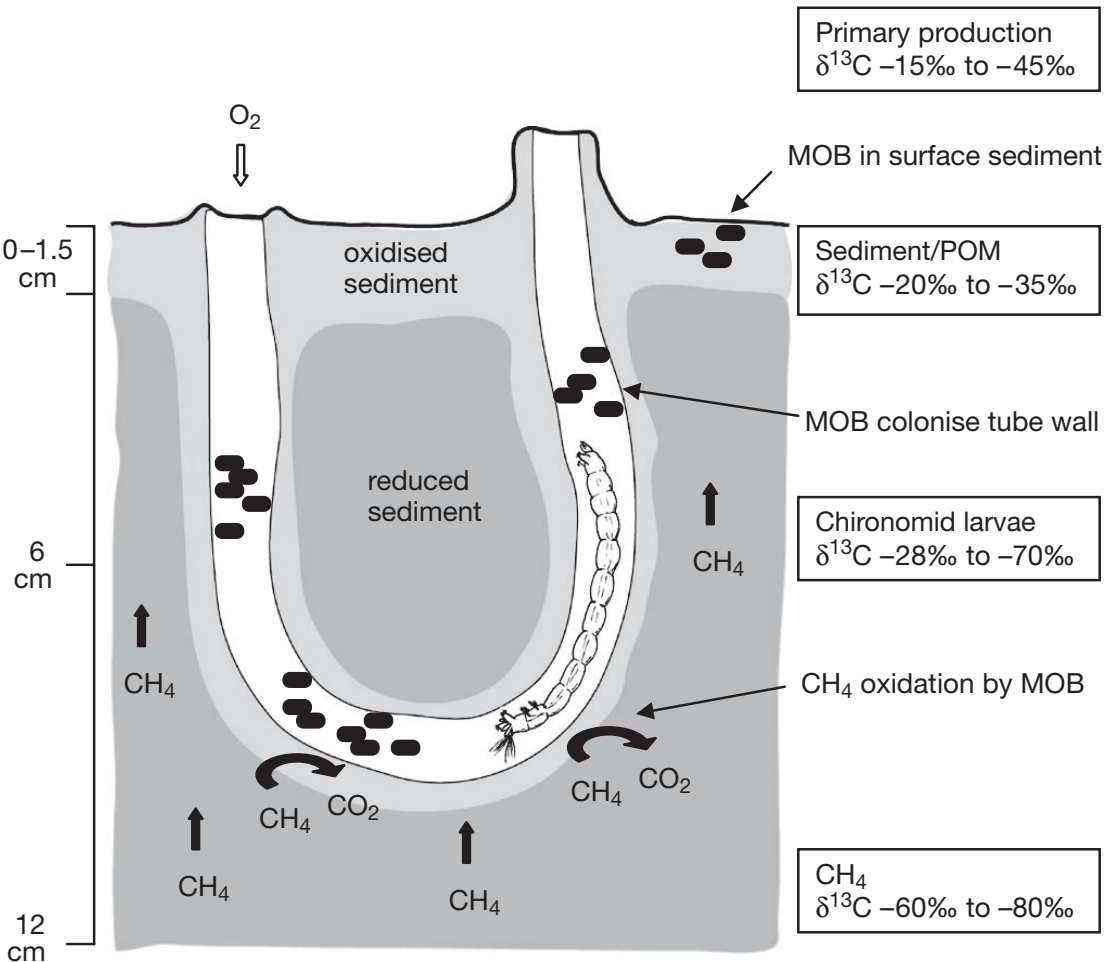

Fig. 1. Hypothetical cross-section through a Chironomus plumosus tube. The larva is thought to maintain an interface of oxic-anoxic conditions by drawing water into the tube and thus creating a microhabitat for methane-oxidising bacteria (MOB). Boxes contain typical $\delta^{13} \mathrm{C}$ values found in our study, and possible carbon pathways are indicated by arrows

$\delta^{13} \mathrm{C}$ and microbial methane turnover activities were determined in parallel over an annual cycle in the 2 lakes studied by Eller et al. (2005). The following specific questions were addressed: (1) Do the lakes exhibit differences in the seasonality of methane turnover and $\delta^{13} \mathrm{C}$ signatures of produced methane? (2) Does larval $\delta^{13} \mathrm{C}$ reflect seasonal changes in methane turnover rates and/or methane $\delta^{13} C$ ? (3) How much chironomid larval biomass can be attributed to biogenic methane?

To answer these questions, sediment cores were sampled every second month in the 2 lakes and analysed for methane production and oxidation rates, as well as the number of MOB. Additionally, the $\delta^{13} \mathrm{C}$ of organic matter in the sediment and the methane produced from the sediment were determined, to define the signatures of potential food sources for chironomid larvae. In parallel, chironomid larvae of the species Chironomus plumosus were sampled and analysed for $\delta^{13} \mathrm{C}$.

\section{MATERIALS AND METHODS}

Two eutrophic lakes in northern Germany were selected as study sites because of their differing morphology and its consequent effect on the water column mixing regimes. Großer Binnensee (54 $20^{\prime} \mathrm{N}, 10^{\circ} 37^{\prime} \mathrm{E}$ )

is a shallow, exposed and polymictic lake, whereas Holzsee $\left(54^{\circ} 10^{\prime} \mathrm{N}, 10^{\circ} 11^{\prime} \mathrm{E}\right)$, although shallow, has a smaller surface area and is protected by surrounding woodland, so that it stratifies and exhibits regular oxygen depletion in the hypolimnion. Some environmental characteristics of the lakes are given in Table 1. Samples were collected from a fixed location in each lake (water column depths: $3 \mathrm{~m}$ in Großer Binnensee

Table 1. Environmental characteristics recorded for Großer Binnensee and Holzsee. Temperature, oxygen concentrations and $\mathrm{pH}$ values are given for water above sediment. Means were calculated from data recorded at 2 mo intervals from August 2003 to August 2004 (DOC: dissolved organic carbon)

\begin{tabular}{|c|c|c|c|}
\hline Parameter & Unit & Großer Binnensee & Holzsee \\
\hline Surface area & $\mathrm{km}^{2}$ & 4.8 & 0.2 \\
\hline Depth (max./mean) & $\mathrm{m}$ & $3.0 / 1.9$ & $6.9 / 3.7$ \\
\hline $\begin{array}{l}\text { Temperature } \\
(\text { mean } \pm \mathrm{SD})\end{array}$ & ${ }^{\circ} \mathrm{C}$ & $13.1 \pm 8.0$ & $10.4 \pm 5.1$ \\
\hline $\mathrm{O}_{2}($ mean $\pm \mathrm{SD})$ & $\mathrm{mg} \mathrm{l}^{-1}$ & $10.2 \pm 1.6$ & $3.9 \pm 4.2$ \\
\hline $\mathrm{pH}$ & & 8.5 & 7.7 \\
\hline $\mathrm{DOC}^{\mathrm{a}}$ & $\mathrm{mg} \mathrm{Cl}^{-1}$ & 8.2 & 5.0 \\
\hline $\mathrm{N}: \mathrm{P}^{\mathrm{a}}$ & & 31 & 24 \\
\hline \multicolumn{2}{|l|}{ Trophic state $^{a}$} & Highly eutrophic & Eutrophic \\
\hline \multicolumn{4}{|c|}{${ }^{a}$ Source of data: Stähr et al. (2002) } \\
\hline
\end{tabular}


and $6.5 \mathrm{~m}$ in Holzsee) from August 2003 to August 2004 at 2 mo intervals. Vertical profiles for temperature and oxygen concentration were determined in the water column at $1 \mathrm{~m}$ depth intervals using a WTW oxygen probe EOT 190 (Oximeter Oxi 191, WTW Germany).

Sampling of chironomid larvae and sediment for stable carbon isotope analyses. Chironomid larvae were collected using an Ekman grab and sieved from the surrounding sediment ( $2 \mathrm{~mm}$ mesh) in situ (Grey et al. 2004a). Chironomus plumosus fourth instar larvae were selected and transported to the laboratory in lake water. Larvae were then placed into filtered water for $24 \mathrm{~h}$ to allow gut clearance (Feuchtmayr \& Grey 2003). Excess faecal material was removed periodically to prevent coprophagy. Individual larvae (20 to 30) were then placed into separate wells of cell culture plates, dried at $60^{\circ} \mathrm{C}$ for $24 \mathrm{~h}$ and stored in a desiccator.

Sediment was sampled adjacent to the larval sampling point $2 \mathrm{~d}$ before the sampling of larvae; 4 to 6 sediment cores were taken to account for lateral sediment heterogeneity. Cores were sealed with rubber stoppers and transported directly to the laboratory, where they were divided into 3 depth layers: the surface $(0$ to $6 \mathrm{~cm})$, the intermediate $(6$ to $12 \mathrm{~cm})$ and the deepest (12 to $20 \mathrm{~cm}$ ) sediment layer. Composite samples for each depth layer were created by combining the material from at least 4 cores and converted into slurries by adding autoclaved tap water $(1: 1, \mathrm{w} / \mathrm{w})$. During slurry preparation, nitrogen was constantly flushed over the samples to prevent oxidation. Sediment samples for stable isotope analysis were acidified (Kelly et al. 2004), oven dried at $60^{\circ} \mathrm{C}$, homogenised and stored in a desiccator.

For carbon stable isotope analysis, samples were weighed (0.5 to $0.7 \mathrm{mg}$ for chironomids and 1.5 to $2.0 \mathrm{mg}$ for sediment) into tin-cups prior to combustion in an Eurovector elemental analyser coupled to a Micromass Isoprime continuous flow isotope ratio mass spectrometer. Stable isotope ratios are given using the $\delta$ notation expressed in units per mil as follows: $\delta^{13} \mathrm{C}(\%)=\left[\left({ }^{13} \mathrm{C} /{ }^{12} \mathrm{C}_{\text {sample }} /{ }^{13} \mathrm{C} /{ }^{12} \mathrm{C}_{\text {standard }}\right)-1\right] \times 1000$. The reference material used was a secondary standard of known relation to the international standard of Vienna Pee Dee belemnite. Repeated analyses of an internal reference $(n=50)$ resulted in a typical precision of $\pm 0.1 \%$.

Potential methane production. Potential methane production rates (MPR) were determined for each sediment depth layer, derived from combined sediment samples as described above. Three replicates of $50 \mathrm{ml}$ slurry from each sediment layer were transferred into sterile serum bottles (total volume $120 \mathrm{ml}$ ), sealed with butyl stoppers and flushed with $\mathrm{N}_{2}$ gas for 30 min to remove residual oxygen. Incubation was performed at $8^{\circ} \mathrm{C}$ in the dark. Potential methane production was followed by headspace sampling with subsequent gas chromatographic analysis (GC-FID), and potential MPRs were calculated by linear regression of the methane increase with incubation time (Eller et al. 2005). At the end of these incubations, the produced methane was collected for stable carbon isotope analysis by gas chromatograph-combustion isotope ratio mass spectrometry (GC-C-IRMS) as described by Krüger et al. (2001).

Potential methane oxidation. To determine potential methane oxidation rates (MOR), slurries of each sediment layer were prepared as described above and transferred in triplicate $(10 \mathrm{ml})$ into sterile serum bottles (total volume $60 \mathrm{ml}$ ). After re-oxidation of the headspace with synthetic air, bottles were sealed with butyl stoppers and methane added to a concentration of $3 \%(\mathrm{v} / \mathrm{v})$ in the headspace. The bottles were incubated at $8^{\circ} \mathrm{C}$ in the dark on a rotary shaker at $120 \mathrm{rpm}$. Methane depletion was followed by headspace sampling and subsequent GC analysis, with the first sample taken 15 min after methane addition and subsequent sampling in $2 \mathrm{~h}$ intervals until final depletion. Potential MORs were calculated by linear regression of the methane depletion over time (Eller et al. 2005).

Cell counts of MOB. Cell numbers of MOB were estimated by the most probable number (MPN) method for all 3 sediment layers as described by Eller et al. (2005). Each slurry sample was diluted in 2-fold steps in 8 replicates (microtiter plates) and in 2 duplicate plates. One of these plates was incubated in an atmosphere containing $20 \% \mathrm{CH}_{4}$ in air and the other in ambient air as a control for heterotrophic growth. Cell numbers and standard deviations for the 8 replicate dilution series from 1 depth layer sample were calculated from positive dilutions by using the code number system and table of Rowe et al. (1977).

Data analysis and modelling. Two-way analysis of variance (ANOVA) was used to test potential MPRs and MORs for significant differences between the 2 lakes and the different sediment depths each month. Additionally, mean values of MOB cell numbers per sediment layer determined over the year were compared between the 2 lakes using a 1-way ANOVA. Differences in larval $\delta^{13} \mathrm{C}$ between the 2 lakes and between sampling dates for each lake were tested for significance with 1-way ANOVA. Tukey tests provided post hoc comparison of means. Regression analyses were used to check for correlations between MPR/MOR and larval $\delta^{13} \mathrm{C}$. All statistical tests were performed using STATISTICA, Version 6.0 (StatSoft).

To estimate the percent contribution of biogenic methane to the carbon content of chironomid larvae, a simple 2-source isotope mixing model (Phillips \& Gregg 2001) was applied, assuming sediment and MOB as 
the only food sources. For these calculations, only the $\delta^{13} \mathrm{C}$ signatures of sediment organic carbon and methane derived from the upper 2 sediment layers ( 0 to $12 \mathrm{~cm}$ sediment depth) were used, because larvae were only seldom detected below this depth (authors' pers. obs.). For each sampling date, means of methane $\delta^{13} \mathrm{C}$ were used to calculate the MOB biomass $\delta^{13} \mathrm{C}$ by applying a fractionation factor of $-16 \%$ for the methanotrophic metabolism (Summons et al. 1994).

\section{RESULTS}

The 2 eutrophic lakes Großer Binnensee (polymictic) and Holzsee (dimictic) exhibited the stratification patterns expected during the annual sampling cycle, i.e. summer stratification in Holzsee and a well mixed water body throughout the year in Großer Binnensee (Stähr et al. 2002). The sediment-water interface was oxic in Großer Binnensee throughout the year and anoxic for approximately $120 \mathrm{~d}$ during autumn 2003 and summer 2004 in Holzsee (Fig. 2a,b).

\section{Seasonal changes and inter-lake differences in chironomid larval $\delta^{13} \mathrm{C}$}

Chironomus plumosus larvae sampled in Großer Binnensee showed only limited seasonal variability in $\delta^{13} \mathrm{C}$ of $2.7 \%$ (min. $-32.3 \%$ and max. $-29.6 \%$; Fig. $2 \mathrm{c}$ ), with slightly more negative values during the winter period. In contrast, large seasonal changes of $17.5 \%$ were detected for larval $\delta^{13} \mathrm{C}$ in Holzsee (min. - $61.7 \%$ and max. $-44.2 \%$; Fig. 2 d), with markedly more negative values over winter. Throughout the year, larval $\delta^{13} \mathrm{C}$ values were consistently more depleted in Holzsee compared to Großer Binnensee (1-way ANOVA, $\mathrm{p}<0.001)$. The annual mean larval $\delta^{13} \mathrm{C}( \pm 1 \mathrm{SD})$ was $-31.1 \pm 1.2 \%$ from Großer Binnensee and $-50.1 \pm 5.9 \%$ o from Holzsee, a difference of $19 \%$. Differences in the inter-individual variability of larval $\delta^{13} \mathrm{C}$ from each lake were also found. In Großer Binnensee, the interindividual variability for a given month was low $(0.76$ to $1.84 \%$ ) , compared to $4.13-9.79 \%$ in Holzsee, where the most ${ }^{13} \mathrm{C}$-depleted individual recorded was $-70.3 \%$.

\section{Sediment and methane $\delta^{13} \mathrm{C}$}

In both lakes, no distinct depth pattern in sediment $\delta^{13} \mathrm{C}$ was found $(-17.6$ to $-18.0 \%$ in Großer Binnensee and -26.6 to $-27.3 \%$ in Holzsee). Sediment was consistently ${ }^{13} \mathrm{C}$-enriched by at least $10 \%$ compared to larval biomass in both lakes (Fig. 2c,d). Additionally, the sediment signatures showed no seasonal pattern, but remained stable throughout the annual period in both lakes and in all 3 depth layers analysed (differences between months were not significant, $\mathrm{p}>0.10$ ). Sediment was consistently more ${ }^{13} \mathrm{C}$-depleted in Holzsee $(-26.9 \pm 0.3 \%)$ than in Großer Binnensee $(-17.8 \pm 0.1 \%$ ) , a difference of $9.1 \%$.

Methane produced in the lake sediments showed seasonal variation in $\delta^{13} \mathrm{C}$ (Fig. 2c,d). In Großer Binnensee, the most negative values of methane $(-70 \%)$ occurred in August 2003 at 0 to $12 \mathrm{~cm}$ sediment depth and in February 2004 at all 3 depths (Fig. 2c). Additionally, large differences were found in methane $\delta^{13} \mathrm{C}$ produced from the different sediment layers for a given month (max. -56.9 to $-72.6 \%$ in August 2003), but no consistent seasonal pattern in relation to sediment depth occurred (Fig. 2c). Mean methane $\delta^{13} \mathrm{C}$ from all 3 sediment layers varied between -61.2 and $-68.8 \%$ throughout the year.

In Holzsee, methane became more ${ }^{13} \mathrm{C}$-depleted with increasing sediment depth during the summer period, whereas in winter (December 2003 and February 2004), this trend was reversed (Fig. 2d). Mean $\delta^{13} \mathrm{C}$ values from all 3 depths varied between -74.8 and $-78.5 \%$; thus, the overall seasonal variability was lower than in Großer Binnensee.

Over the annual cycle, methane $\delta^{13} \mathrm{C}$ of the 3 sediment layers ranged between -55 and $-73 \%$ for Großer Binnensee (annual mean $-64.6 \pm 2.4 \%$ ) and -73 and $-88 \%$ for Holzsee (annual mean $-76.4 \pm 1.3 \%$ ), with a mean difference of $11.8 \%$ between the 2 lakes (Fig. 2c).

\section{Seasonal changes in potential methane production}

Potential MPRs were determined in the 3 sediment layers (Table 2). In Großer Binnensee, seasonal changes of potential MPRs in the upper 2 sediment layers showed no clear annual pattern, ranging from 1.7 to $8.6 \mathrm{nmol} \mathrm{CH}_{4} \mathrm{~g}_{\mathrm{dw}}{ }^{-1} \mathrm{~h}^{-1}$ and from 3.1 to $9.0 \mathrm{nmol} \mathrm{CH}_{4}$ $\mathrm{g}_{\mathrm{dw}}{ }^{-1} \mathrm{~h}^{-1}$ in the surface and intermediate layers, respectively (Table 2). Only the deepest sediment layer exhibited a clear maximum in potential MPR in February. In Holzsee, only the potential MPR in the surface sediment layer showed substantial seasonal changes, with highest rates in August 2003 and June 2004 and lowest in February 2004 (Table 2). There was typically a significant difference in potential MPR between the 2 lakes $(\mathrm{p}<0.001)$ and the 3 depths $(\mathrm{p}<0.01)$ for each sampling occasion (except February 2004). In general, mean potential MPR calculated for all 3 sediment depth layers at each sampling time point were almost 3 to 4 times lower in Großer Binnensee than in Holzsee.

The pattern of potential MPR across the 3 sediment layers generally remained characteristic for the lakes (Table 2). In Großer Binnensee, highest annual mean 

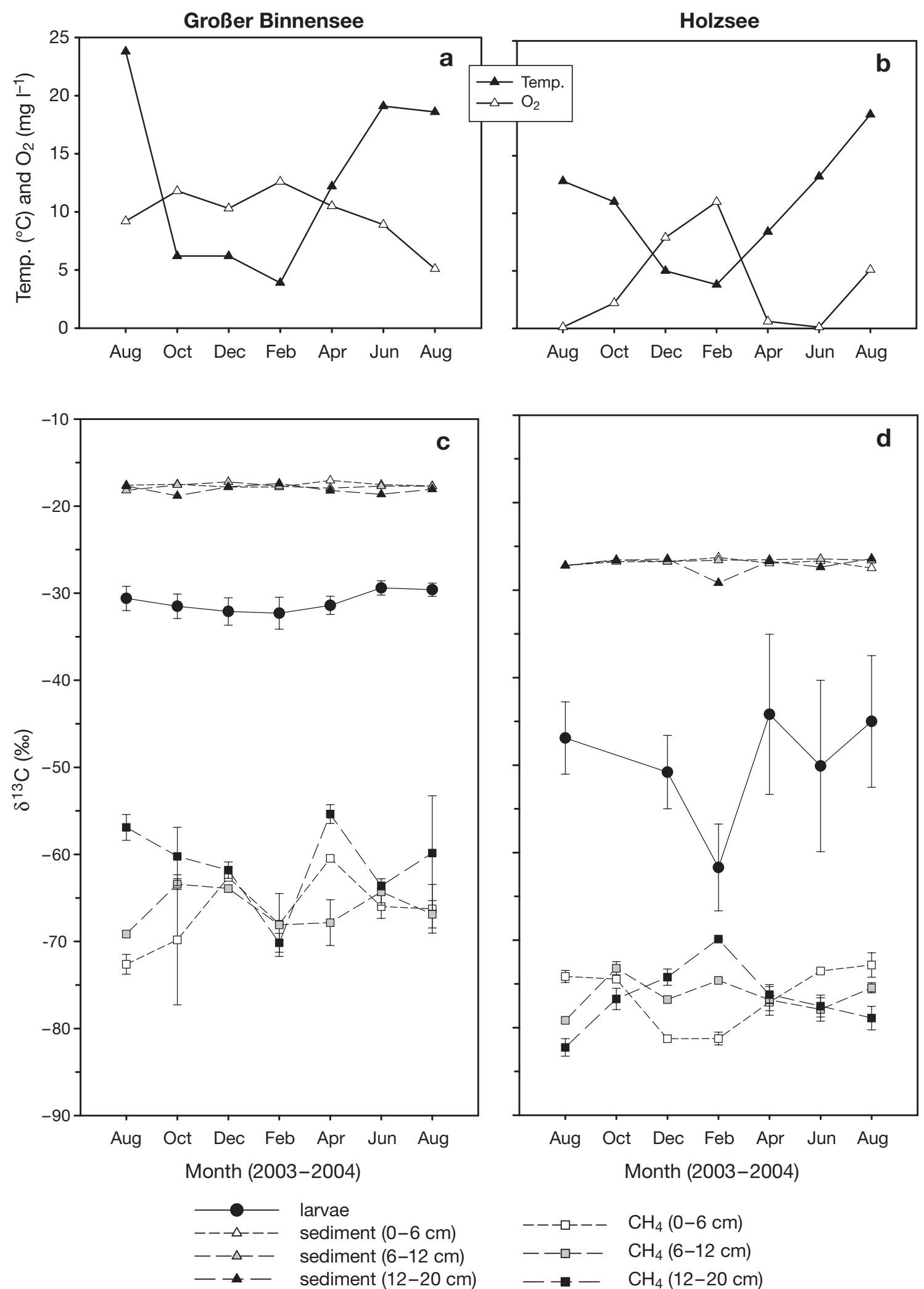

Fig. 2. Seasonal variation of physico-chemical parameters and stable carbon isotopes measured in (a,c) Großer Binnensee and $(b, d)$ Holzsee over an annual cycle: $(a, b)$ temperature and oxygen concentrations in the water column directly above the sediment surface; $(\mathrm{c}, \mathrm{d}) \delta^{13} \mathrm{C}(\%)$ of sediment, of Chironomus plumosus larval biomass (mean $\left.\pm \mathrm{SD}\right)$, and of methane produced in sediment lurries (mean $\pm \mathrm{SD})$ 
Table 2. Comparison of potential methane production rates (MPR), potential methane oxidation rates (MOR) and cell numbers of methaneoxidising bacteria (MOB) over an annual cycle in sediment cores of Großer Binnensee and Holzsee. MPR, MOR $(n=3)$ and MOB $(n=8)$ are given as means \pm SD. Bold/italic print denotes maximum values per depth; bold print denotes minimum values per depth. Ext.: extreme value that is high above the variation normally measured

\begin{tabular}{|c|c|c|c|c|c|c|c|}
\hline \multirow{2}{*}{ Date } & \multirow{2}{*}{$\begin{array}{l}\text { Depth } \\
\text { (cm) }\end{array}$} & \multicolumn{3}{|c|}{ Großer Binnensee } & \multicolumn{3}{|c|}{ Holzsee ${ }^{-}{ }^{-} \mathrm{H}^{-}$} \\
\hline & & $\begin{array}{c}\text { MPR } \\
\left(\mathrm{nmol} \mathrm{CH} \mathrm{g}_{\mathrm{dw}}{ }^{-1} \mathrm{~h}^{-1}\right)\end{array}$ & $\begin{array}{c}\text { MOR } \\
\left(\mu \mathrm{mol} \mathrm{CH} \mathrm{g}_{\mathrm{dw}}{ }^{-1} \mathrm{~h}^{-1}\right)\end{array}$ & $\begin{array}{c}\mathrm{MOB} \\
\left(10^{5} \mathrm{~g}_{\mathrm{dw}}{ }^{-1}\right)\end{array}$ & $\begin{array}{c}\text { MPR } \\
\left(\mathrm{nmol} \mathrm{CH} \mathrm{g}_{\mathrm{dw}}{ }^{-1} \mathrm{~h}^{-1}\right)\end{array}$ & $\begin{array}{c}\text { MOR } \\
\left(\mu \mathrm{mol} \mathrm{CH} \mathrm{g}_{\mathrm{dw}}{ }^{-1} \mathrm{~h}^{-1}\right)\end{array}$ & $\begin{array}{c}\text { MOB } \\
\left(10^{5} \mathrm{~g}_{\mathrm{dw}}{ }^{-1}\right)\end{array}$ \\
\hline Aug 2003 & $\begin{array}{c}0-6 \\
6-12 \\
12-20\end{array}$ & $\begin{array}{l}\mathbf{1 . 7} \pm \mathbf{0 . 4} \\
7.8 \pm 0.4 \\
3.5 \pm 4.9\end{array}$ & $\begin{array}{l}1.1 \pm 0.01 \\
1.6 \pm 0.05 \\
0.9 \pm 0.03\end{array}$ & $\begin{array}{l}1.4 \pm 0.3 \\
\mathbf{3 . 5} \pm \mathbf{0 . 8} \\
\mathbf{3 . 1} \pm \mathbf{0 . 5}\end{array}$ & $\begin{array}{c}39.7 \pm 4.2 \\
18.9 \pm 0.3 \\
9.0 \pm 2.1\end{array}$ & $\begin{array}{l}4.4 \pm 0.44 \\
\mathbf{4 . 5} \pm \mathbf{0 . 4 5} \\
\mathbf{4 . 2} \pm \mathbf{0 . 0 4}\end{array}$ & $\begin{array}{c}7.8 \pm 2.1 \\
\mathbf{1 6 . 9} \pm \mathbf{3 . 4} \text { (ext.) } \\
4.8 \pm 0.7\end{array}$ \\
\hline Oct 2003 & $\begin{array}{c}0-6 \\
6-12 \\
12-20\end{array}$ & $\begin{array}{l}5.2 \pm 1.1 \\
\mathbf{9 . 0} \pm \mathbf{1 . 2} \\
1.1 \pm 0.3\end{array}$ & $\begin{array}{l}0.9 \pm 0.05 \\
0.8 \pm 0.04 \\
0.3 \pm 0.01\end{array}$ & $\begin{array}{l}1.2 \pm 0.2 \\
2.5 \pm 0.4 \\
0.7 \pm 0.1\end{array}$ & $\begin{array}{c}27.0 \pm 1.9 \\
16.5 \pm 1.6 \\
5.9 \pm 0.6\end{array}$ & $\begin{array}{l}3.0 \pm 0.32 \\
\mathbf{2 . 8} \pm \mathbf{0 . 5 9} \\
1.9 \pm 0.10\end{array}$ & $\begin{array}{l}8.3 \pm 2.5 \\
5.1 \pm 1.1 \\
3.0 \pm 0.5\end{array}$ \\
\hline Dec 2003 & $\begin{array}{c}0-6 \\
6-12 \\
12-20\end{array}$ & $\begin{array}{l}5.0 \pm 0.4 \\
5.3 \pm 0.3 \\
1.6 \pm 0.2\end{array}$ & $\begin{array}{l}0.7 \pm 0.02 \\
0.6 \pm 0.02 \\
0.3 \pm 0.03\end{array}$ & $\begin{array}{l}0.7 \pm 0.2 \\
\mathbf{0 . 6} \pm \mathbf{0 . 3} \\
\mathbf{0 . 6} \pm \mathbf{0 . 2}\end{array}$ & $\begin{array}{l}17.1 \pm 6.2 \\
20.7 \pm 0.8 \\
12.0 \pm 2.3\end{array}$ & $\begin{array}{l}\mathbf{2 . 8} \pm \mathbf{0 . 3 1} \\
2.9 \pm 0.18 \\
2.6 \pm 0.29\end{array}$ & $\begin{array}{l}\mathbf{3 . 3} \pm \mathbf{0 . 5} \\
5.0 \pm 1.0 \\
\mathbf{0 . 7} \pm \mathbf{0 . 3}\end{array}$ \\
\hline Feb 2004 & $\begin{array}{c}0-6 \\
6-12 \\
12-20\end{array}$ & $\begin{array}{c}5.9 \pm 0.1 \\
15.8 \pm 9.9(\text { ext. }) \\
8.3 \pm \mathbf{1 . 1}\end{array}$ & $\begin{array}{l}\mathbf{0 . 5} \pm \mathbf{0 . 0 4} \\
1.2 \pm 0.04 \\
\mathbf{0 . 9} \pm \mathbf{0 . 0 2}\end{array}$ & $\begin{array}{l}3.1 \pm 0.9 \\
2.2 \pm 0.5 \\
1.1 \pm 0.4\end{array}$ & $\begin{array}{c}\mathbf{1 1 . 6} \pm \mathbf{0 . 6} \\
13.4 \pm 0.6 \\
\mathbf{1 . 9} \pm \mathbf{0 . 5}\end{array}$ & $\begin{array}{l}4.4 \pm 0.18 \\
3.6 \pm 0.15 \\
\mathbf{1 . 2} \pm \mathbf{0 . 1 3}\end{array}$ & $\begin{array}{l}7.6 \pm 1.3 \\
6.0 \pm 1.1 \\
3.1 \pm 0.6\end{array}$ \\
\hline Apr 2004 & $\begin{array}{c}0-6 \\
6-12 \\
12-20\end{array}$ & $\begin{array}{l}8.6 \pm 0.5 \\
\mathbf{3 . 1} \pm \mathbf{1 . 1} \\
5.2 \pm 0.7\end{array}$ & $\begin{array}{l}0.8 \pm 0.16 \\
\mathbf{0 . 4} \pm \mathbf{0 . 0 3} \\
\mathbf{0 . 2} \pm \mathbf{0 . 0 5}\end{array}$ & $\begin{array}{l}\mathbf{0 . 6} \pm \mathbf{0 . 2} \\
1.2 \pm 0.2 \\
2.1 \pm 0.2\end{array}$ & $\begin{array}{l}29.0 \pm 2.6 \\
16.6 \pm 2.6 \\
10.4 \pm 0.9\end{array}$ & $\begin{array}{l}5.6 \pm 0.33 \\
4.5 \pm 0.12 \\
3.7 \pm 0.10\end{array}$ & $\begin{array}{l}5.8 \pm 1.6 \\
3.0 \pm 1.2 \\
6.4 \pm \mathbf{1 . 1}\end{array}$ \\
\hline Jun 2004 & $\begin{array}{c}0-6 \\
6-12 \\
12-20\end{array}$ & $\begin{array}{l}2.7 \pm 0.3 \\
8.3 \pm 0.9 \\
\mathbf{0 . 9} \pm \mathbf{0 . 8}\end{array}$ & $\begin{array}{l}0.6 \pm 0.03 \\
0.8 \pm 0.01 \\
0.3 \pm 0.02\end{array}$ & $\begin{array}{l}1.4 \pm 0.4 \\
2.0 \pm 0.5 \\
0.8 \pm 0.2\end{array}$ & $\begin{array}{c}33.7 \pm 0.9 \\
\mathbf{1 2 . 6} \pm \mathbf{1 . 8} \\
4.1 \pm 0.6\end{array}$ & $\begin{array}{l}4.6 \pm 0.08 \\
3.3 \pm 0.19 \\
1.8 \pm 0.09\end{array}$ & $\begin{array}{l}3.7 \pm 0.6 \\
2.3 \pm 1.1 \\
2.8 \pm 0.6\end{array}$ \\
\hline Aug 2004 & $\begin{array}{c}0-6 \\
6-12 \\
12-20\end{array}$ & $\begin{array}{l}6.3 \pm 1.8 \\
6.7 \pm 0.8 \\
5.7 \pm 5.7\end{array}$ & $\begin{array}{l}\mathbf{1 . 1} \pm \mathbf{0 . 1 0} \\
1.0 \pm 0.07 \\
0.5 \pm 0.01\end{array}$ & $\begin{array}{l}\mathbf{3 . 6} \pm \mathbf{0 . 6} \\
2.5 \pm 0.3 \\
1.3 \pm 0.5\end{array}$ & $\begin{array}{c}18.2 \pm 1.1 \\
14.4 \pm 0.6 \\
6.3 \pm 0.7\end{array}$ & $\begin{array}{l}4.9 \pm 0.07 \\
4.2 \pm 0.64 \\
4.0 \pm 0.04\end{array}$ & $\begin{array}{l}7.3 \pm 1.3 \\
\mathbf{1 . 1} \pm \mathbf{0 . 5} \\
5.6 \pm 1.1\end{array}$ \\
\hline Variation & $0-6$ & $1.7-8.6$ & $0.5-1.1$ & $0.6-3.6$ & $11.6-39.7$ & $2.8-5.6$ & $3.3-8.3$ \\
\hline Aug 2003 & $6-12$ & $3.1-9.0(15.8)$ & $0.4-1.6$ & $0.6-3.5$ & $12.6-20.7$ & $2.8-4.5$ & $1.1-6.0(16.9)$ \\
\hline to Aug 2004 & $12-20$ & $0.9-8.3$ & $0.2-0.9$ & $0.6-3.1$ & $1.9-12.0$ & $1.2-4.2$ & $0.7-6.4$ \\
\hline
\end{tabular}

potential MPRs were found in the intermediate sediment layer (6 to $12 \mathrm{~cm}, 8 \mathrm{nmol} \mathrm{CH}_{4} \mathrm{~g}_{\mathrm{dw}}{ }^{-1} \mathrm{~h}^{-1}$ ), whereas lower rates were detected in the surface and deepest layers (5 and $4 \mathrm{nmol} \mathrm{CH}_{4} \mathrm{~g}_{\mathrm{dw}}{ }^{-1} \mathrm{~h}^{-1}$, respectively). In Holzsee, a different depth pattern of potential MPR was found, with highest potential MPR in the surface layer (annual mean of $25 \mathrm{nmol} \mathrm{CH}_{4} \mathrm{~g}_{\mathrm{dw}}{ }^{-1} \mathrm{~h}^{-1}$ ), decreasing with increasing sediment depth to $16 \mathrm{nmol} \mathrm{CH}_{4}$ $\mathrm{g}_{\mathrm{dw}}{ }^{-1} \mathrm{~h}^{-1}$ and $7 \mathrm{nmol} \mathrm{CH} \mathrm{CH}_{\mathrm{dw}}{ }^{-1} \mathrm{~h}^{-1}$.

\section{Potential methane oxidation and biomass of MOB}

Potential MORs in Großer Binnensee showed only small seasonal changes. A small peak occurred at the end of the summer period in all 3 sediment layers, and an additional peak occurred in February 2004 in the deeper 2 layers (Table 2). Beside these seasonal differences, potential MORs were comparable for all 3 sediment layers, ranging between 0.2 and $1.6 \mu \mathrm{mol} \mathrm{CH}_{4}$ $\mathrm{g}_{\mathrm{dw}}{ }^{-1} \mathrm{~h}^{-1}$ (Table 2). Annual mean potential MOR for each respective layer showed only slight differences between the surface and the intermediate layers $(0.8$ and $0.9 \mu \mathrm{mol} \mathrm{CH}_{4} \mathrm{~g}_{\mathrm{dw}}{ }^{-1} \mathrm{~h}^{-1}$, respectively), whereas in the deepest layer, rates decreased by almost $50 \%$ to $0.5 \mu \mathrm{mol} \mathrm{CH} \mathrm{CH}_{\mathrm{dw}}{ }^{-1} \mathrm{~h}^{-1}$.
Corresponding to potential MOR, cell numbers of MOB in Großer Binnensee showed no substantial differences between the sediment layers. Annual mean cell numbers for the surface, intermediate and deepest layers of $1.6 \times 10^{5}, 2.1 \times 10^{5}$ and $1.4 \times 10^{5}$ cells $\mathrm{g}_{\mathrm{dw}}{ }^{-1}$, respectively, were detected. Seasonal changes in MOB cell numbers in Großer Binnensee were weak, ranging from $0.6 \times 10^{5}$ to $3.6 \times 10^{5} \mathrm{~g}_{\mathrm{dw}}{ }^{-1}$ in all 3 sediment layers (Table 2).

In Holzsee, potential MOR in the surface and intermediate layers increased from $2.8 \pm 0.3$ and $2.9 \pm$ $0.2 \mu \mathrm{mol} \mathrm{CH}_{4} \mathrm{~g}_{\mathrm{dw}}{ }^{-1} \mathrm{~h}^{-1}$ in December 2003 to $5.6 \pm 0.3$ and $4.5 \pm 0.1 \mathrm{mmol} \mathrm{CH}_{4} \mathrm{~g}_{\mathrm{dw}}{ }^{-1} \mathrm{~h}^{-1}$ in April 2004, respectively; no clear annual trend was detected for the deepest layer (Table 2). A similar depth pattern was found for potential MOR as for potential MPR, with highest mean rates detected throughout the year in the surface layer $\left(4.2 \mu \mathrm{mol} \mathrm{CH}_{4} \mathrm{~g}_{\mathrm{dw}}{ }^{-1} \mathrm{~h}^{-1}\right)$, gradually decreasing with increasing depth to 3.7 and $2.7 \mu \mathrm{mol} \mathrm{CH}_{4} \mathrm{~g}_{\mathrm{dw}}{ }^{-1} \mathrm{~h}^{-1}$. Significant differences between the 2 lakes $(p<0.01)$ and for all 3 depth layers ( $p<0.05$ ) were found during the whole year. Potential MORs in Großer Binnensee were 3 to 4 times lower than in Holzsee (Table 2).

In contrast to potential MOR, cell numbers of MOB in Holzsee showed no clear seasonal trend, and only small differences between the 3 sediment layers were 
detected (Table 2). Nevertheless, annual mean cell counts for MOB in Holzsee gradually decreased from the top to the bottom layer, reflecting the depth pattern detected for potential MOR. Four times more MOB cells $\left(6.3 \times 10^{5} \mathrm{~g}_{\mathrm{dw}}{ }^{-1}\right)$ were found in surface sediments from Holzsee compared to Großer Binnensee. Differences between the 2 lakes in MOB cell numbers from each depth were significant on all sampling occasions $(\mathrm{p}<0.05)$.

\section{Methane turnover and larval $\delta^{13} \mathrm{C}$}

When comparing methane turnover and larval $\delta^{13} \mathrm{C}$, mean values of MPR and MOR from the 2 upper sediment layers (0 to $12 \mathrm{~cm}$ ) were used. An analysis of all potential MPRs and potential MORs taken together from both lakes, and corresponding larval $\delta^{13} \mathrm{C}$, revealed that larval $\delta^{13} \mathrm{C}$ was significantly and negatively correlated with potential MPR $(p<0.01)$ and potential MOR $(p<0.001$; Fig. 3$)$. The data sets from the
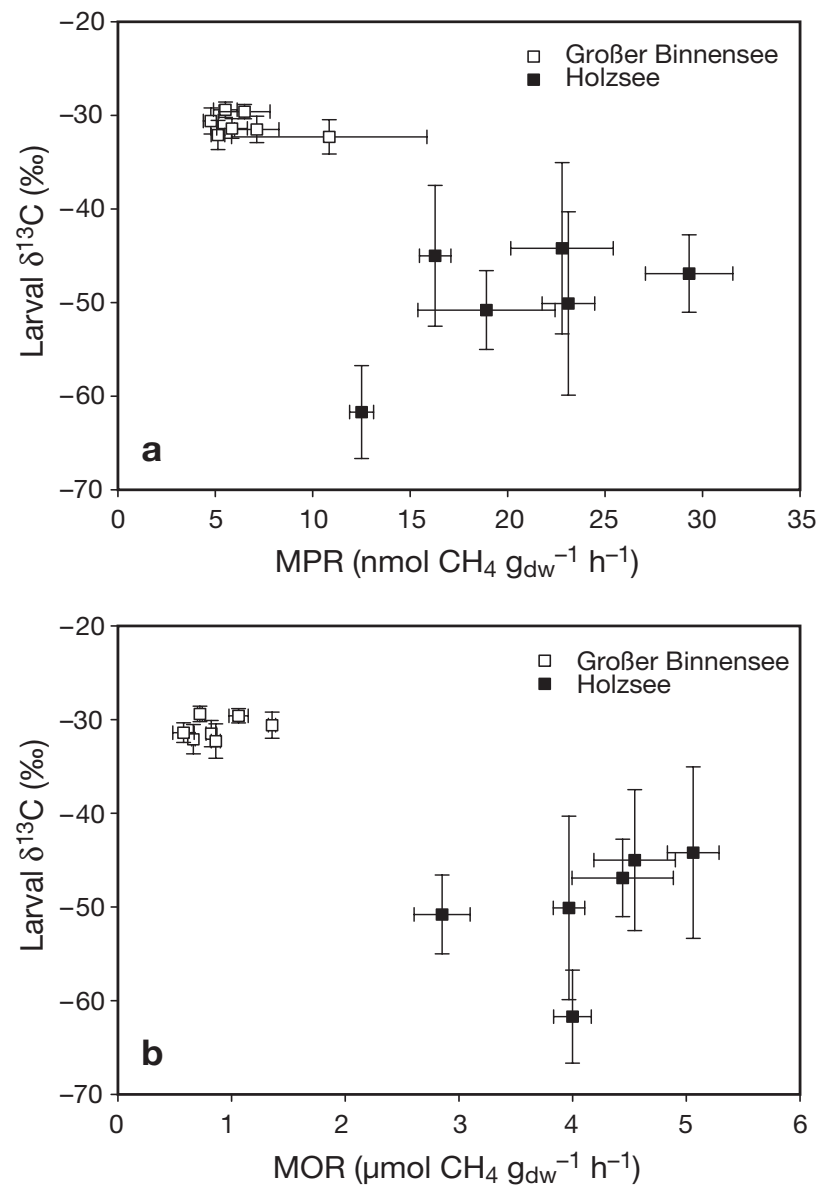

Fig. 3. Correlation between (a) potential methane production rates (MPR) and (b) potential methane oxidation rates (MOR) of the upper 2 sediment layers $(0$ to $12 \mathrm{~cm}$ ) with chironomid larval $\delta^{13} \mathrm{C}$
2 lakes were clearly separated, with higher methane turnover rates and more ${ }^{13} \mathrm{C}$-depleted larvae occurring in the dimictic Holzsee (Fig. 3).

\section{DISCUSSION}

\section{Seasonal patterns of methane turnover compared to larval $\delta^{13} \mathrm{C}$ signatures}

Small seasonal changes in chironomid larval $\delta^{13} \mathrm{C}$ values were detected in the polymictic lake (Großer Binnensee), as was expected from lake characteristics and predicted by the study of Grey et al. (2004b). In parallel, only small changes in methane turnover rates were observed during the entire year in this lake, indicating a relationship between methane turnover activities and the larval diet. However, although the annual mean larval $\delta^{13} \mathrm{C}$ of $-31.1 \%$ was consistently depleted relative to the sediments $(-18 \%)$ and phytoplankton (ca. $-24 \%$ : Grey et al. 2004b, J. Grey unpubl. data), it indicates only a limited contribution of methanederived carbon to larval diet.

Indeed, potential MPRs in Großer Binnensee were 3to 4 -fold lower than in the dimictic Holzsee (Table 2) and in another dimictic eutrophic lake, Lake Dagow (Casper 1996, Glissmann et al. 2004). These low potential MPRs and the limited seasonality coincided with an oxygenated sediment-water interface throughout the year (Fig. 2a), inhibiting this strictly anaerobic process. Additionally, chironomid larvae occur at high densities in Großer Binnensee (Eller et al. 2005), leading to oxygen penetration into deeper sediment layers due to bioturbation (Granéli 1979, Jörgensen \& Revsbech 1985, Frenzel 1990) and the consequent inhibition of methane production in what would otherwise be anoxic regions. Furthermore, the relatively high sulphate concentrations detected in Großer Binnensee (up to $0.5 \mathrm{mmol}^{-1}$; G. Eller unpubl. data) could lead to inhibition of methanogens due to substrate competition with sulphate-reducing bacteria (Chidthaisong \& Conrad 2000). The limited availability of methane, in turn, probably led to the low potential MOR and MOB cell numbers detected (Table 2), even though the oxygenated sediment-water interface represented preferable conditions for methane oxidation. Thus, although Großer Binnensee is a eutrophic lake, the microbial methane turnover rates were relatively low and seasonally constant.

Theoretically, larval $\delta^{13} \mathrm{C}$ in Großer Binnensee could be depleted relative to sediments and phytoplankton due to assimilation of chemoautotrophic bacterial biomass rather than MOB, as discussed in detail in Grey \& Deines (2005). Such chemoautotrophic bacteria might be stimulated in parallel to $\mathrm{MOB}$, associated with the 
oxic/anoxic interfaces and the nutrients within the tubes built by the larvae (Fig. 1) (Kajan \& Frenzel 1999, Grey \& Deines 2005 and references therein). Nevertheless, we assume MOB to be the more likely ${ }^{13} \mathrm{C}$ depleted carbon source.

Seasonal variation in methane $\delta^{13} \mathrm{C}$ (Fig. 2c) was not reflected in the larvae, and the potential contribution of methane-derived carbon to larval biomass estimated from the 2-source isotope mixing model was $20.6 \pm$ $2.2 \%$ (annual mean $\pm 1 \mathrm{SD}$; Fig. 4).

In Holzsee, strong seasonal variation of larval $\delta^{13} \mathrm{C}$ occurred, with the most negative mean value of $-62 \%$ detected in February 2004 (Fig. 2d), indicating a substantial contribution of methane-derived carbon to larval diet during winter. Nevertheless, the seasonal changes in potential MPR detected in the surface sediment $(0$ to $6 \mathrm{~cm}$ ) showed the opposite trend to larval $\delta^{13} \mathrm{C}$, with lowest potential MPR in February and highest in June 2004 (Table 2). In the latter month, the larvae were most ${ }^{13} \mathrm{C}$-enriched (Fig. 2d); thus, changes in potential MPR were not correlated to larval $\delta^{13} \mathrm{C}$.

The decrease of potential MPR in autumn in Holzsee could be explained by the re-oxygenation of the sediment-water interface inhibiting methane production after water column overturn (Fig. 2b). Anoxic conditions in the water above the sediment were re-established in April 2004 in Holzsee (Fig. 2b). Presumably, at this time, increased substrate concentrations in the sediment following a spring phytoplankton bloom (Stähr et al. 2002) allowed high potential MPR. Thus, the decrease in larval $\delta^{13} \mathrm{C}$ during the winter coincided with a decrease of phytoplankton in the water column. This was traceable by Secchi depth measurements,

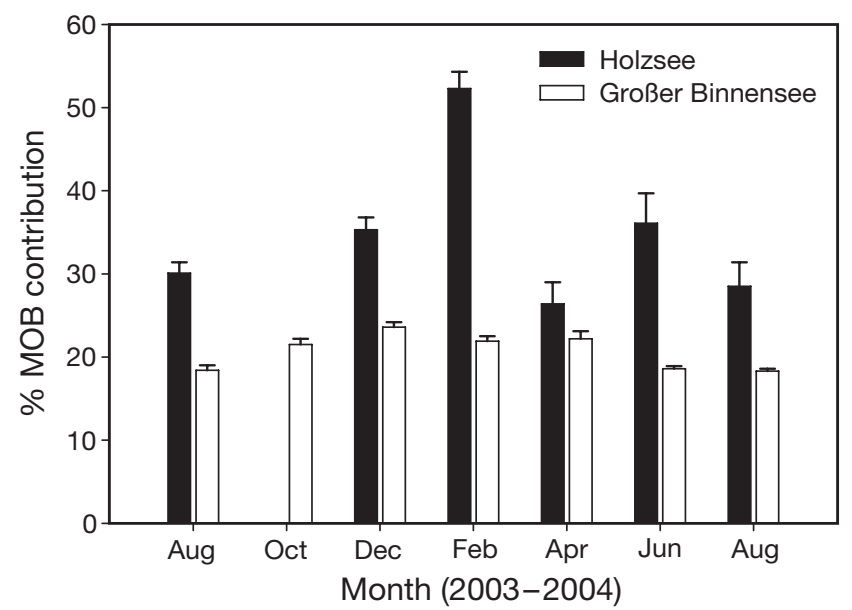

Fig. 4. Estimated contribution (\%) of carbon derived from methane-oxidising bacteria (MOB) to Chironomus plumosus larval biomass in Holzsee and Großer Binnensee. Values were calculated using a 2-source isotope mixing model, assuming sediment carbon and MOB as the only carbon sources $($ mean $\pm \mathrm{SE})$ which can be used to estimate the approximate density of phytoplankton populations in the water column (Lorenzen 1980, Canfield \& Hodgson 1983). Secchi depth increased from $1.0 \mathrm{~m}$ in August to $1.6 \mathrm{~m}$ in October. A maximum of $4.5 \mathrm{~m}$ was measured in December, decreasing to $3.1 \mathrm{~m}$ at the end of January (E. ReckMieth pers. comm.). These data suggest that less organic matter from algae was available during winter. The increase in larval $\delta^{13} \mathrm{C}$ in spring coincided with the phytoplankton spring bloom (Secchi depth between March and April: 1.4 to $2.0 \mathrm{~m}$; E. Reck-Mieth pers. comm.); this implies a greater proportion of algal biomass in larval diet in early spring and a seasonally varying contribution of methane-derived carbon. Nevertheless, larvae in Holzsee were ${ }^{13} \mathrm{C}$-depleted relative to sediment by approximately $23.2 \%$ o throughout the year, indicating that methane-derived carbon was not only important after the autumn overturn of the water column, but also during periods when algal biomass was available as suggested by Grey et al. (2004b).

In contrast to potential MPR, potential MOR in the upper 2 sediment layers of Holzsee (0 to $12 \mathrm{~cm}$ ) increased steadily from December 2003 to April 2004 (Table 2), supporting the hypothesis of an increased importance of methane-derived carbon to larval diet in winter. Additionally, methane $\delta^{13} \mathrm{C}$ was most negative in December 2003 and February 2004 in the surface sediment (Fig. 2d), corresponding to high MOB cell numbers (Table 2). This co-occurrence might have led to increased availability of ${ }^{13} \mathrm{C}$-depleted MOB biomass. A comparison of the seasonal patterns of potential MPR, potential MOR and larval $\delta^{13} \mathrm{C}$ in Holzsee strongly indicates that the larvae predominantly fed on MOB biomass in the surface sediment. Therefore, based upon this first comprehensive data set spanning an entire year, we propose that methane oxidation activity and the biomass of MOB are the primary factors determining the contribution of methane-derived carbon for the larval diet. This finally confirms the assumptions based on carbon isotope signatures alone by other authors (Bunn \& Boon 1993, Grey et al. 2004a, b, Kelly et al. 2004). Furthermore, this also supports the observation that higher numbers of Eubacteria (including MOB) rather than Archaea (including methanogens) are associated with chironomid larvae (Eller et al. 2007, this issue).

The higher methane turnover rates detected throughout the year in Holzsee compared to in Großer Binnensee support the hypothesis of Kelly et al. (2004) that the microbial methane cycle is of greater importance for the overall carbon cycle in dimictic than in polymictic lakes. This was also reflected in the annual mean $\delta^{13} \mathrm{C}$ values recorded from the 2 lakes: sediment differing by $9 \%$, methane by $12 \%$ and larval biomass by $19 \%$, indicating a higher contribution of methane-derived carbon to larval diet in the dimictic Holzsee. 


\section{Correlation of methane turnover and larval $\delta^{13} \mathrm{C}$ at single sampling time points}

In addition to the overall seasonal patterns, methane turnover rates and larval $\delta^{13} \mathrm{C}$ were compared. Taking potential MPR/MOR and corresponding larval $\delta^{13} \mathrm{C}$ from both lakes together, a significant negative correlation was detected (Fig. 3). This indicates that the possible incorporation of methane-derived biomass strongly depends on methane turnover rates. On average, chironomid larvae in Holzsee were 1.5- to 2-fold more reliant on methanotrophic biomass than were larvae in Großer Binnensee (Fig. 4).

When looking at both lakes independently, the same negative correlation between potential MPR or potential MOR and larval $\delta^{13} \mathrm{C}$ should be found (as in Fig. 3). However, our data rather suggest the opposite and seem to contradict the hypothesis that higher methane turnover rates lead to more ${ }^{13} \mathrm{C}$-depleted larvae. Such a lack of correlation may be ascribed to an insensitivity of the sampling methodology. Larvae in the lake live in tubes and promote the growth of a specialised microbial community (especially MOB) in this microenvironment (Fig. 1) (Kajan \& Frenzel 1999). However, the bulk sediment samples taken for analysis of potential MPR and potential MOR did not exactly represent these tube environs and probably did not reflect exactly the methane turnover rates in close proximity to the larvae. Whereas methane production is a process which is predominately controlled by the absence of oxygen and the amount of easily degradable organic matter, methane oxidation is largely controlled by sediment oxygen and methane availability (Segers 1998). There are several reasons for the discrepancy found between the theoretically expected higher methane turnover rates when oxygen was available (here in winter in Holzsee) and the detected minimal potential rates. Of course, the constant incubation temperature of $8^{\circ} \mathrm{C}$ used in rates determination throughout the year did not mimic in situ conditions and probably influenced the rates recorded (Höfle 1979, Glissmann et al. 2004, Mor et al. 2006). Besides temperature, under field conditions, MOB may have been limited due to decreased substrate $\left(\mathrm{CH}_{4}\right)$ availability (Segers 1998) or, for example, due to the presence of the competitive substrate ammonium $\left(\mathrm{NH}_{4}{ }^{+}\right)$, influencing $\mathrm{CH}_{4}$ oxidation (Steudler et al. 1989, King \& Schnell 1994). Furthermore, the time required for isotopic equilibrium between these larvae and diet is not known (but see Goedkoop et al. 2006); thus, methane turnover rates and larval $\delta^{13} \mathrm{C}$ from the same sampling time point are likely to be out of phase. Moreover, the marked interindividual variability in larval $\delta^{13} \mathrm{C}$ detected in Holzsee indicates that larvae fed on carbon sources with distinct $\delta^{13} \mathrm{C}$ : strongly ${ }^{13} \mathrm{C}$-depleted MOB biomass compared to relatively ${ }^{13} \mathrm{C}$-enriched algal biomass or sediment
(Grey et al. 2004b). The strong isotopic heterogeneity in basal carbon sources was probably masked in bulk sediment samples, and, thus, no correlation of methane turnover rates and larval $\delta^{13} \mathrm{C}$ at single time points was found in Holzsee.

One further source of methanotrophic biomass could be MOB from the water column, but this would require larvae to filter them from suspension using nets as they do for fresh algae. Detailed studies of the mesh of Chironomus plumosus nets revealed an effective pore size of 12 to $17 \mu \mathrm{m}$ (Walshe 1947, 1951), which is too large for bacteria. Thus, unless the pelagic MOB are associated with flocs, it is unlikely that such a source contributes substantially.

\section{CONCLUSIONS}

The comparison of chironomid larval $\delta^{13} \mathrm{C}$ and methane turnover activities in a polymictic and a stratifying lake revealed that seasonal changes in both parameters occurred only in the stratifying lake. A detailed investigation of the methane cycle indicated that besides the overall importance of the methane cycle in the sediment, the contribution of methanederived carbon to larval diet was primarily determined by methane oxidation activity and the availability of MOB biomass. Nevertheless, direct correlations of larval $\delta^{13} \mathrm{C}$ and methane turnover rates at single sampling time points were not found. This could be due to the sampling technique that did not fully capture the larval tubes and their specialised microbial community, and/or due to the lack of isotopic equilibrium between larvae and diet. Therefore, further studies will focus on the microenvironments of the tubes and the time required for chironomid larvae to achieve dietary isotopic equilibrium.

Acknowledgements. We thank E. Blohm-Sievers, K. F. Ettwig, C. Schleker and I. Schulz for help with fieldwork, H. Buhtz and A. Möller for assistance with sample preparation for stable isotope analyses, M. Gehre and U. Günther for help with gas sample isotope analysis, and M. Krüger for helpful discussions. Graf Waldersee and F. Schrage kindly provided access to Großer Binnensee and Holzsee, respectively. E. Reck-Mieth from the lake-monitoring programme (Kreis Plön) provided Secchi depth data. We thank 2 anonymous reviewers for critical and constructive comments on the manuscript. This work was supported by the Max Planck Society.

\section{LITERATURE CITED}

Bunn SE, Boon PI (1993) What sources of organic carbon drive food webs in billabongs? A study based on stable isotope analysis. Oecologia 96:85-94

Cabana G, Rasmussen JB (1996) Comparison of aquatic food chains using nitrogen isotopes. Proc Natl Acad Sci USA 93:10844-10847 
Canfield DE, Hodgson LM (1983) Prediction of Secchi disc depths in Florida lakes: impact of algal biomass and organic color. Hydrobiologia 99:51-60

Casper P (1996) Methane production in littoral and profundal sediments of an oligotrophic and a eutrophic lake. Arch Hydrobiol Spec Issue Adv Limnol 48:253-259

Chidthaisong A, Conrad R (2000) Specificity of chloroform, 2-bromoethanesulfonate and fluoroacetate to inhibit methanogenesis and other anaerobic processes in anoxic rice field soil. Soil Biol Biochem 32:977-988

Childress JJ, Fisher CR, Brooks JM, Kennicutt MC, Bidigare R, Anderson AE (1986) A methanotrophic marine molluscan (Bivalvia, Mytilidae) symbiosis: mussels fueled by gas. Science 233:1306-1308

Eller G, Deines P, Grey J, Richnow HH, Krüger M (2005) Methane cycling in lake sediments and its influence on chironomid larval $\delta^{13} \mathrm{C}$. FEMS Microbiol Ecol 54:339-350

Eller G, Deines P, Krüger M (2007) Possible sources of methane-derived carbon for chironomid larvae. Aquat Microb Ecol 46:283-293

Feuchtmayr H, Grey J (2003) Effect of preparation and preservation procedures on carbon and nitrogen stable isotope determinations from zooplankton. Rapid Commun Mass Spectrom 17:2605-2610

Fisher CR (1990) Chemoautotrophic and methanotrophic symbioses in marine invertebrates. Rev Aquat Sci 2: 399-436

Frenzel P (1990) The influence of chironomid larvae on sediment oxygen microprofiles. Arch Hydrobiol 119:427-437

Fry B, Sherr EB (1984) $\delta^{13} \mathrm{C}$ measurements as indicators of carbon flow in marine and freshwater ecosystems. Contrib Mar Sci 27:13-47

Glissmann K, Chin KJ, Casper P, Conrad R (2004) Methanogenic pathway and archaeal community structure in the sediment of eutrophic Lake Dagow: effect of temperature. Microb Ecol 48:389-399

Goedkoop W, Åkerblom N, Demandt MH (2006) Trophic fractionation of carbon and nitrogen stable isotopes in Chironomus riparius reared on food of aquatic and terrestrial origin. Freshw Biol 51:878-886

Granéli W (1979) Influence of Chironomus plumosus larvae on the oxygen uptake of sediment. Arch Hydrobiol 87 : 385-403

Grey J (2002) A chironomid conundrum: queries arising from stable isotopes. Verh Internat Verein Limnol 28:102-105

Grey J, Deines P (2005) Differential assimilation of methanotrophic and chemoautotrophic bacteria by lake chironomid larvae. Aquat Microb Ecol 40:61-66

Grey J, Jones RI, Sleep D (2001) Seasonal changes in the importance of the source of organic matter to the diet of zooplankton in Loch Ness, as indicated by stable isotope analysis. Limnol Oceanogr 46:505-513

Grey J, Kelly A, Jones RI (2004a) High intraspecific variability in carbon and nitrogen stable isotope ratios of lake chironomid larvae. Limnol Oceanogr 49:239-244

Grey J, Kelly A, Ward S, Sommerwerk N, Jones RI (2004b) Seasonal changes in the stable isotope values of lakedwelling chironomid larvae in relation to feeding and life cycle variability. Freshw Biol 49:681-689
Höfle MG (1979) Effects of sudden temperature shifts on pure cultures of four strains of freshwater bacteria. Microb Ecol $5: 17-26$

Jörgensen BB, Revsbech NP (1985) Diffusive boundary layers and the oxygen uptake of sediments and detritus. Limnol Oceanogr 30:111-122

Kajan R, Frenzel P (1999) The effect of chironomid larvae on production, oxidation and fluxes of methane in a flooded rice soil. FEMS Microbiol Ecol 28:121-129

Kelly A, Jones RI, Grey J (2004) Stable isotope analysis provides fresh insights into dietary separation between Chironomus anthracinus and C. plumosus. J N Am Benthol Soc 23:287-296

King GM, Schnell S (1994) Effect of increasing atmospheric methane concentration on ammonium inhibition of soil methane consumption. Nature 370:282-284

Kiyashko SI, Narita T, Wada E (2001) Contribution of methanotrophs to freshwater macroinvertebrates: evidence from stable isotope ratios. Aquat Microb Ecol 24:203-207

Kohzu A, Kato C, Iwata T, Kishi D, Murakami M, Nakano S, Wada E (2004) Stream food web fueled by methanederived carbon. Aquat Microb Ecol 36:189-194

Krüger M, Frenzel P, Conrad R (2001) Microbial processes influencing methane emission from rice fields. Global Change Biol 7:49-63

Levin LA, Michener RH (2002) Isotopic evidence for chemosynthesis-based nutrition of macrobenthos: the lightness of being at Pacific methane seeps. Limnol Oceanogr 47: $1336-1345$

Lorenzen MW (1980) Use of chlorophyll-Secchi disk relationships. Limnol Oceanogr 25:371-372

Mor S, De Visscher A, Ravindra K, Dahiya RP, Chandra A, Van Cleemput O (2006) Induction of enhanced methane oxidation in compost: temperature and moisture response. Waste Manag 26:381-388

Peterson BJ, Fry B (1987) Stable isotopes in ecosystem studies. Annu Rev Ecol Syst 18:293-320

Phillips DL, Gregg JW (2001) Uncertainty in source partitioning using stable isotopes. Oecologia 127:171-179

Rowe R, Todd R, Waide J (1977) Microtechnique for MostProbable-Number analysis. Appl Environ Microbiol 33: $675-680$

Segers R (1998) Methane production and methane consumption: a review of processes underlying wetland methane fluxes. Biogeochemistry 41:23-51

Stähr E, Reck-Mieth E, Runge U, Guse I (2002) 10 Jahre SeenBeobachtung im Kreis Plön 1991-2000, Kreis Plön (ed), Plön

Steudler PA, Bowden RD, Mellilo JM, Aber JD (1989) Influence of nitrogen fertilisation on methane uptake in temperate forest soil. Nature 341:314-316

Summons RE, Jahnke LL, Roksandic Z (1994) Carbon isotopic fractionation in lipids from methanotrophic bacteria: relevance for interpretation of the geochemical record of biomarkers. Geochim Cosmochim Acta 58:2853-2863

Walshe BM (1947) Feeding mechanism of Chironomus larvae. Nature 160:474-476

Walshe BM (1951) The feeding habits of certain chironomid larvae (subfamily Tendipedinae). Proc Zool Soc Lond 121: $63-79$

Submitted: June 21, 2006; Accepted: November 26, 2006

Proofs received from author(s): January 24, 2007 